\title{
Shielding of Gamma Radiation by Using Porous Materials
}

\author{
S. GEDIK AND A.F. BAYTAŞ* \\ Energy Institute, Istanbul Technical University, 34469 Istanbul, Turkey
}

\begin{abstract}
In this study, the gamma radiation attenuation was investigated for different composite metallic foams, soil and standard sand samples. Gamma transmission technique with narrow beam geometry, Co-60 radiation source were used in experimental studies. The measurements were used to calculate the linear attenuation coefficients and porosities of these materials. The results were compared according to radiation attenuation and porosity distribution of porous media. The metallic foams had large and non-homogeneous porosity values, therefore sand and soil showed better radiation attenuation property. However, the saturated silica foam had large ability of gamma ray attenuation as well as dry soil.
\end{abstract}

DOI: 10.12693/APhysPolA.128.B-174

PACS: $29.90 .+\mathrm{r}$

\section{Introduction}

Gamma radiation shielding is a main part of radiation protection for indispensable applications of radiation such as medicine, industry, nuclear researches and their applications. Therefore, many studies are investigated on different shielding materials. A shielding material produced by a metallurgical solid waste containing lead was used for gamma radiation shielding in [1]. This material was proposed as a shielding material against gamma radiation for buildings. Shielding aprons were manufactured from barium sulfate as a potential substitute for the lead aprons used most commonly for medical radiation shielding in [2]. Especially medical and industrial applications of gamma radiation require large amount of shielding materials. The composite metal foams which have porosity are light materials [3-5]. The potential of utilizing the light-weight composite metal foams as shielding material replacing current heavy materials was used for attenuation of low energy gamma ray with additional advantages such as high energy absorption and excellent heat rejection capabilities [6]. In this study, the gamma ray attenuation and porosity values for metallic foams and other porous media which contains silicon were examined by gamma transmission technique.

\section{Materials and methods}

As the gamma rays pass through a dry porous medium, the intensity of the gamma rays is attenuated in accordance with the Lambert-Beer law as follows:

$$
I=I_{0} \exp (-\mu x) \text {. }
$$

$I_{0}, I, x[\mathrm{~cm}]$ and $\mu\left[\mathrm{cm}^{-1}\right]$ show respectively the incoming radiation intensity, the intensity of attenuated radiation by material, the material thickness and the linear attenuation coefficient of material, respectively. The porosity of

\footnotetext{
*corresponding author; e-mail: fbaytas@itu.edu.tr
}

the materials $(\varepsilon)$ is calculated by using attenuated radiation intensity of dry and fully saturated porous material as follows [7]:

$$
\varepsilon=\left(1+\frac{x \mu_{\mathrm{w}}}{\ln \left(I / I_{\mathrm{s}}\right)}\right)^{-1}
$$

$I_{\mathrm{S}}$ and $\mu_{\mathrm{w}}\left[\mathrm{cm}^{-1}\right]$, respectively, refer to the attenuated radiation intensity of fully saturated material and the linear attenuation coefficient of water.

In this study, the radiation attenuations of porous media were examined by using gamma transmission setup with narrow beam geometry as shown in Fig. 1. The experimental studies were performed for dry and fully saturated porous materials by using Co-60 radiation source (1.33 MeV). Two kinds of metallic open cell foams, soil and standard sand were used as porous media and the water was used for saturation of media.

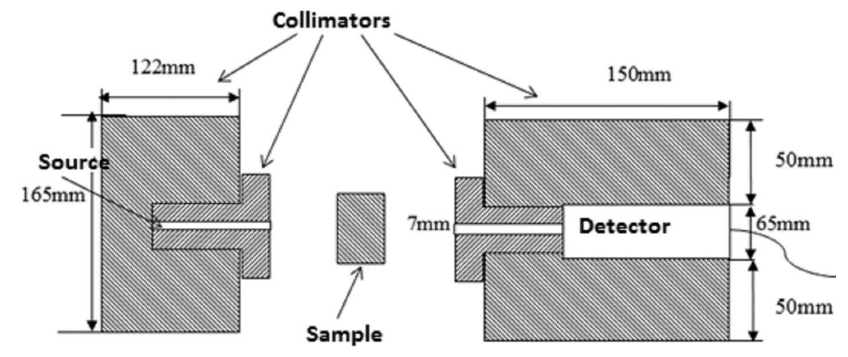

Fig. 1. Gamma transmission setup with narrow beam geometry.

\section{Results and discussions}

In this study, the gamma transmission measurements were carried out with dry porous materials, then all of the materials were saturated by water and the gamma transmissions from saturated materials were measured in the same experimental conditions. In all of the experiments, the measurements were done in the three vertical points of the center line of the materials. $\mathrm{SiC}$ and $\mathrm{Al}_{2} \mathrm{O}_{3}$ foams were represented by S1-6, A1-4, respectively in the study. The linear attenuation coefficients of each samples were 
calculated according to Eq. (1) by using the experimental results. The average of the attenuation coefficients for three different points is shown in Table I.

TABLE I

The average linear attenuation coefficients of dry metallic foams.

\begin{tabular}{c|c|c|c}
\hline \hline $\begin{array}{c}\text { Dry metallic } \\
\text { foam }\end{array}$ & $\begin{array}{c}\mu_{\text {mean }}\left[\mathrm{cm}^{-1}\right] \\
\text { S1 }\end{array}$ & $\begin{array}{c}\text { Dry metallic } \\
\text { foam }\end{array}$ & $\begin{array}{c}\mu_{\text {mean }} \\
{\left[\mathrm{cm}^{-1}\right]}\end{array}$ \\
S2 & 0.012051 & $\mathrm{~S} 6$ & 0.040991 \\
S3 & 0.026988 & $\mathrm{~A} 1$ & 0.043627 \\
S4 & 0.019808 & $\mathrm{~A} 2$ & 0.074482 \\
S5 & 0.034753 & $\mathrm{~A} 3$ & 0.014073 \\
& & $\mathrm{~A} 4$ & 0.027505
\end{tabular}

The same measurements were performed for the samples fully saturated with water in a plexiglass container to evaluate their porosities. Equation (2) was used to evaluate the porosities of the samples. As a result, the mean porosity values of $\mathrm{SiC}$ between $0.651171-0.579493$ and of $\mathrm{Al}_{2} \mathrm{O}_{3}$ foams 0.458046 were found, respectively.

The dry and wet studies were performed for standard Ottawa sand and soil sample from Samsun which is in the north of Turkey. The properties of these materials are given by Table II. The major component of sand and soil is $\mathrm{SiO}_{2}$ and $\mathrm{SiC}$ metal foam has also $\mathrm{Si}$ component. A comparison according to linear attenuation coefficients, which represent radiation attenuation property of material, for dry and saturated porous media and porosities of $\mathrm{SiC}$ metal foam, sand and soil were given in Table III.

TABLE II

The properties of standard Ottawa sand [7] and the chemical components of soil sample [8].

\begin{tabular}{c|c|c|c}
\hline \hline \multicolumn{2}{c|}{ Ottawa sand } & \multicolumn{2}{c}{ Samsun soil } \\
\hline $\begin{array}{c}\text { Chemical } \\
\text { structure }\end{array}$ & $\mathrm{SiO}_{2}$ & $\begin{array}{c}\text { Chemical } \\
\text { structure }\end{array}$ & {$[\%]$} \\
\hline $\begin{array}{c}\text { structure } \\
\text { mesh }[\mu \mathrm{m}]\end{array}$ & clean, particulate & $\mathrm{SiO}_{2}$ & 59.00 \\
$\begin{array}{c}\text { average particle } \\
\text { radius }[\mu \mathrm{m}]\end{array}$ & $600-800$ & $\mathrm{Al}_{2} \mathrm{O}_{3}$ & 20.60 \\
$\begin{array}{c}\text { volumetric density } \\
{\left[\mathrm{g} / \mathrm{cm}^{3}\right]}\end{array}$ & 720 & $\mathrm{Fe}_{2} \mathrm{O}_{3}$ & 10.60 \\
& 1.74 & $\mathrm{CaO}$ & 3.02
\end{tabular}

TABLE III

The comparison of materials including Si.

\begin{tabular}{c|c|c|c|c|c}
\hline \hline Material & $\left(I / I_{0}\right)_{\mathrm{dry}}$ & $\begin{array}{c}\mu_{\text {dry }} \\
{\left[\mathrm{cm}^{-1}\right]}\end{array}$ & $\left(I / I_{0}\right)_{\text {saturated }}$ & $\begin{array}{c}\mu_{\text {saturated }} \\
{\left[\mathrm{cm}^{-1}\right]}\end{array}$ & $\varepsilon_{\text {mean }}$ \\
\hline $\begin{array}{c}\text { S3(SiC) } \\
\text { soil }\end{array}$ & 0.961191 & 0.019808 & 0.847171 & 0.083435 & 0.579493 \\
$\begin{array}{c}\text { standard } \\
\text { sand }\end{array}$ & 0.819898 & 0.090397 & 0.772188 & 0.117579 & 0.318290
\end{tabular}

Otherwise, SiC metallic foam blocks were consecutively put into between the collimators and source, the measurements were taken from upper-mid points of the blocks. The same procedure was applied to $\mathrm{Al}_{2} \mathrm{O}_{3}$ foams, the radiation attenuation results was given in Fig. 2 as relative counts versus thickness.

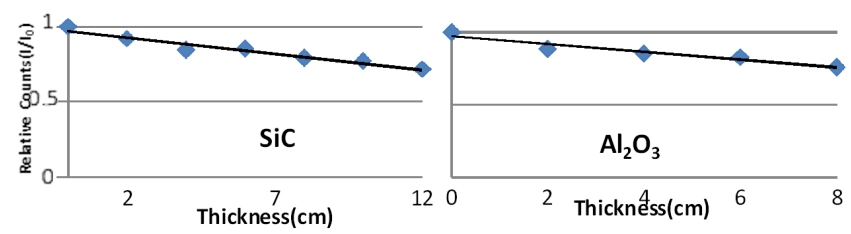

Fig. 2. Radiation attenuation in $\mathrm{SiC}$ and $\mathrm{Al}_{2} \mathrm{O}_{3}$ metallic foam blocks.

\section{Conclusion}

Radiation attenuation properties and porosities of metallic open cell foams, sand, and soil were examined by using gamma ray attenuation technique. $\mathrm{SiC}$ and $\mathrm{Al}_{2} \mathrm{O}_{3}$ metallic foams have large porosity values, therefore the linear attenuation coefficients of sand and soil were found greater than that of foams. The porosity values and also linear attenuation coefficients of foams were not homogeneous locally. However, the saturated $\mathrm{SiC}$ metallic foam had a linear attenuation coefficient almost that of dry soil. Also, it is observed that the radiation was attenuated by $\mathrm{Al}_{2} \mathrm{O}_{3}$ foam blocks in shorter distance than by $\mathrm{SiC}$ blocks.

\section{References}

[1] M. Erdem, O. Baykara, M. Doğrucu, F. Kuluozturk, Radiat Phys. Chem. 79, 917 (2010).

[2] S.C. Kim, K.R. Dong, W. Chung, Ann. Nucl. En. 47, 1 (2012).

[3] B.H. Smith, S. Szyniszewski, J.F. Hajjar, B.W. Schafer, S.R. Arwade, J. Construct. Steel Res. 71, 1 (2012).

[4] H. Nakajima, Prog. Mater. Sci. 52, 1091 (2007).

[5] X. Siqi, M. Bourham, A. Rabiei, Mater. Des. 31, 2140 (2010).

[6] S. Chen, M. Bourham, A. Rabiei, Radiat. Phys. Chem. 96, 27 (2014).

[7] A. İshakoğlu, A.B. Baytas, Appl. Radiat. Isotopes 56, 60 (2002).

[8] M.C. Cebe, M.Sc. Thesis, Istanbul Technical University, Energy Institute, Istanbul 2014. 